\title{
The Mediating Role of Effort in the Relationship between Job Involvement and Job Performance: A Case Study of Private Higher Education Institutes in Eastern Indonesia
}

\author{
Muhammad Akhsan Tenrisau ${ }^{1}$, Siti Haerani², Haris Maupa ${ }^{3}$ and Muhammad Ismail Pabo ${ }^{4}$ \\ ${ }^{1}$ STIE NOBEL Indonesia, Indonesia, e-mail: akhsan.tenrisau@,stienobel-indonesia.ac.id \\ ${ }^{2}$ Hasanuddin University, Indonesia \\ ${ }^{3}$ Hasanuddin University, Indonesia \\ ${ }^{4}$ Hasanuddin University, Indonesia
}

\begin{abstract}
The objective of this study is to clarify ambiguities in the literature regarding the relationships among three key constructs of work relationships: job involvement, effort, and job performance. This present study aims to make at least three contributions: (1) to add to the theory building on how job involvement has an effect on job performance; (2) to investigate the mediating role of effort as a process underlying the relationship between job involvement and job performance; (3) to provide information to the authorities of higher educational institutions on how to improve job involvement, effort and lecturers' performance.

Keywords: Job involvement, Effort, Job performance
\end{abstract}

\section{Introduction}

According to the Law of the Republic of Indonesia number 14 year 2005 on teachers and lecturers, a lecturer must hold a master academic qualification, competence, certified, physically and mentally healthy, and able to achieve the national education goals. In this law, competence refers to pedagogical, personality, professional, and social competence. Based on this description, lecturers have roles, duties and responsibilities that are very important in generating the national development vision. However, it is discouraging to note that there are still 37,684 people or around 13.6 percent of university lecturers in Indonesia who are still undergraduate graduates (Forlap DIKTI data, 2018). In addition to this educational qualification shortcoming, lecturers' publication of scientific papers in international journals indexed by Scopus is also still very low. SCImagojr, an online portal that indexes the journals and country scientific indicators developed from the information contained in the Scopus database reports the number of scientific publications from 240 countries, shows that Indonesia is ranked 55th with the number of publications of 54,146 documents. Compared to neighboring countries, Indonesia, for example, lags far behind with Malaysia ranked 34th with a total of 214,883 publications, Singapore ranked 32 with 241,351 publications and even with Thailand with 139,682 publications ranked 43rd.

One important factor that is considered effecting the performance of lecturers is job attitudes. Job attitudes have attracted the attention of practitioners and researchers in the past three decades because its assumptions that job attitudes are related to performance (Staw, et al, 1986). One of the job attitudes that referred to in this study is job involvement. Although job involvement is assumed to be related to job performance, the results of studies generally do not show a consistent relationship. Different studies have shown a positive, negative, or no relationship between job involvement and job performance. In general, job involvement is considered to have an important influence on individual and company performance outcomes (Lawler, 1986), but the results of Brown's (1996) meta-analysis show that job involvement does not stimulate the level of significance of employee performance directly. In contrast, empirical studies from Blau (1993); Brown and Leigh (1996) and Gardner et al., (1989), found a positive relationship between job involvement and performance.

This study aims to make several important contributions to the job involvement literature and its relationship with performance. First, this study adds to the theory building on how job involvement has an effect on job performance. Second, by exploring the mediating role of effort, this study tests a 
possible intervening mechanism in order to explain the relationship between job involvement and behavioral outcomes. Third, to the best of the authors' knowledge, the mediating role of effort between job involvement and job performance in private universities are empirically unexplored, especially in the Indonesian context. Therefore, the present study aims to explain the relationship between job involvement and behavioral outcomes and can help management of higher educational institutions to improve job involvement, effort and lecturers' performance.

Job Involvement. At first, there was no specific definition for job involvement because the concept was unclear. Many researchers tried to define it by adopting different views. Therefore, job involvement has received great attention from researchers over the past three decades. Although various studies try to investigate job involvement, the concept of work involvement itself is still unclear about what and how it must be viewed.

The concept of job involvement was first introduced by Lodahl and Kejner (1965) and received much attention because it was in the field of organizational behavior and work psychology. Job involvement can be described as the extent to which a person's performance influences his self-esteem (Lodahl and Kejner, 1965). Work involvement is the internalization of values about the goodness of work or the importance of work in individuals. With a higher level of job involvement, individuals will spend more time and effort on their work.

Robbins and Judge (2013) define job involvement as the degree to which a person identifies himself with a job, actively participates, and considers performance is important for self-esteem. Paullay, et al., (1994) defines job involvement as the extent to which a person is cognitively busy, engaged, and concerned with his current job. Job involvement is considered a major determinant of organizational effectiveness (Pfeffer, 1994) and individual motivation (Hackman and Lawler, 1971). As for Kanungo (1982), he defines job involvement as individual commitment or psychological identification of a person towards his/her work. Job involvement is how individuals see their work as a relationship with the work environment, the work itself and how their work and life mixed. This definition implies that employees who are very involved in their work will see work "as an important part of their self-concept" (Lawler and Hall, 1970), and that work defines a person's self-concept on a large scale (Kanungo, 1982).

The Relationship between Job Involvement and Job Performance. Job involvement emphasizes the extent to which a person is psychologically involved and care about his current job (Paullay et al., 1994). Job involvement in this case involves internalizing core values about the goodness of work in individual values (Lodahl and Kejner, 1965). Employees who exhibit a high level of job involvement consider assignments in their workplace to be a very important part of their lives and regardless of whether they feel good about themselves or not, a large part depends on how they perform at their respective jobs. Although job involvement is considered as an important factor affecting the performance of individuals and organizations (Lawler, 1986), but the results of the study did not show significant results (e.g. studies by Brown, 1996 and Diefendorff, 2002). In contrast, empirical studies from Blau, (1993); Brown and Leigh, (1996) and Gardner, et al., (1989) found a positive relationship between job involvement and performance. The model of their research predicts that effort mediates the relationship between job involvement and job performance. Theoretically, individuals who are more involved in their work will put more effort.

Job involvement is predicted to have a significant impact on various important organizational outcomes. Regarding job performance, Brown (1996) argues that employee work behavior must be categorized as a consequence of job involvement and hypothesizes that job involvement influences employee motivation and effort which then determines performance. The latest research conducted by Hettiararchchi \& Jayarathna (2014) proves that there is a positive relationship between job involvement and job performance. In line with Hettiararchchi \& Jayarathna (2014), a study conducted by Chughtai (2008) reiterates that job involvement is an important determinant of individual performance. Chughtai (2008) in his study of lecturers in Pakistan proved that lecturers with a high 
level of involvement in their work tend to produce higher performance. From these views, this research proposes a proposition:

Proposition 1: Job involvement is positively related to job performance

Effort. Conceptually, effort is often considered equal to motivation. For example, motivation is defined as the amount of effort devoted to work-related tasks (Campbell and Pritchard, 1976; Steers et al., 2004). But a more meaningful explanation then arises that distinguishes motivation from effort. Motivation is considered to represent the psychological state or tendency of individuals in relation to options that involve the direction, intensity, and determination of behavior. The effort represents the strength, energy, or activity where work is carried out.

Lloyd (2008) then argues that effort and motivation are actually two different constructs, where motivation is "the degree to which employees are willing to spend effort on work" (Dubinsky \& Hartley, 1986). On the other hand, effort is "the means by which motivation is translated into the achievement of work" (Parsons, 1968). Individuals with the same level of motivation can issue different levels of effort (Eisenberger, 1998). As for Lloyd (2003, in Lloyd 2008) defines effort as the voluntary effort employees spend that lies above the minimum level of effort needed to maintain a job and is directed toward organizational goals.

The Mediating Role of Effort. It is generally believed that the influence of positive job involvement on employee motivation and effort leads to a higher level of job performance (Brown, 1996). Previous studies indicate support for these claims. Research from Brown and Leigh (1996) for example, showed that work involvement had a direct and indirect effect on performance through effort. More specifically, they found that the relationship was modest but statistically significant effect of involvement on performance became insignificant when effort was put into the model. Brown and Leigh (1996) found that job involvement is positively related to job performance through effort. Rabinowitz and Hall (1977) emphasize that job involvement increases as a result of an increase in satisfaction in work and in turn, the more involved a person is, the greater the effort he will incur in doing his work. This shows the mediating effect of the effort on the relationship. In addition, employees who psychologically identify themselves with work tend to sacrifice more time and energy at work (Kahn, 1990), and this extra effort increases the likelihood that they will perform well and get rewarded (Kanungo, 1982; Lawler \& Hall, 1970). From the above view, this research proposes a proposition:

Proposition 2: Effort mediated the effect of job involvement on job performance

Conceptual Framework. In light of the relationships established among the variables described by the past studies in literature review, a conceptual framework can be deduced as depicted in Figure 1 below:

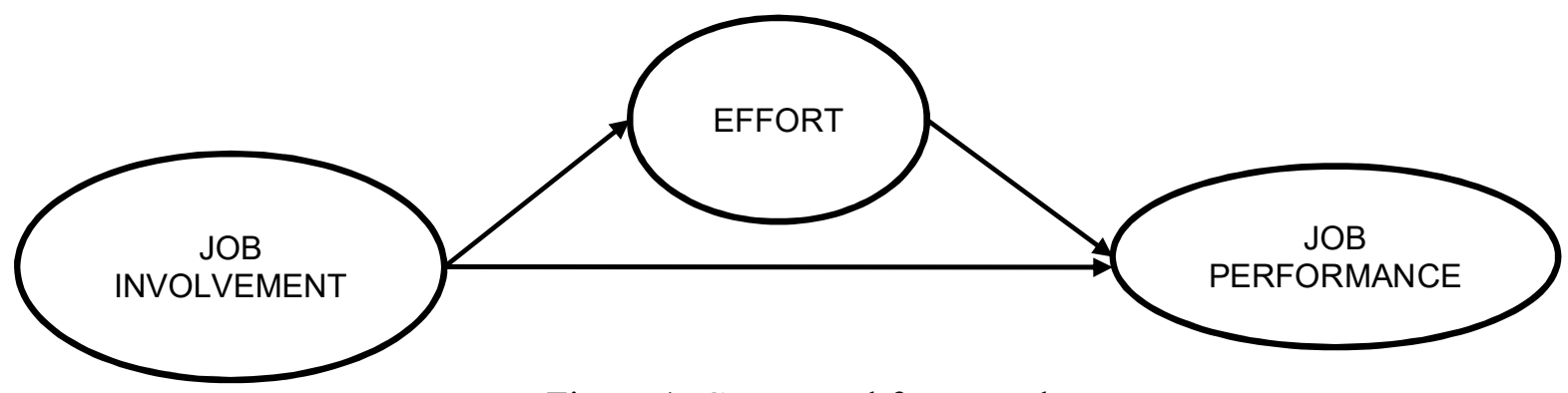

Figure 1: Conceptual framework

\section{Research Methodology}

The population of this study is determined based on the following rules: must serve as permanent lecturers at active private universities, have been certified as professional lecturers, possess National Lecturer Identification Number (NIDN) and functional positions. These characteristics are considered to represent fairly heterogeneous information about the characteristics of lecturers. There are 8,859 
lecturers in South Sulawesi. However, only 2,538 lecturers are eligible based on fore mentioned rules and to determine number of samples for this study, slovin method is employed.

Disproportionate stratified random sampling technique will be conducted to draw a sample of lecturers working in 153 private sector universities in South Sulawesi. To collect data, around 346 lecturers which consist of instructors, assistant professors, associate professors and professors will be contacted through LinkedIn, Facebook, and universities' faculty directory, and will be requested to participate in the online survey. In addition, e-mails are going to be sent to request the different departmental heads of each university to distribute the survey invitation email along with the survey site's URL to their faculty members. Lecturers who are willing to take part in the survey will be told to access the survey website voluntarily at any convenient time and place. To strictly control survey participants' eligibility and to ensure that valid responses are obtained, screening questions (such as educational background, functional position and certification) are included.

Job involvement will be measured by using a scale adapted from the multidimensional work engagement model of Yoshimura (1996). This scale measures emotional job involvement, cognitive job involvement and behavioral job involvement. The job involvement scale consists of 15 items with an interval scale of 1 to 5 . The lowest score (1) shows the very low level of job involvement perceived by the lecturer and the highest score (5) illustrates the very high level of job involvement.

Effort is measured using the scale adopted from the Discretionary Effort Scale from Lloyd (2008). This questionnaire uses an interval scale between 1 to 5 . The lowest score (1) from the respondent's answer shows the very low lecturer effort and the highest score (5) shows the very high level of effort the lecturer has.

Job performance variables in this study will be measured by using instrument developed based on the lecturers' performance indicators from Fortunato and Waddel (1981). The measurement using an interval scale between 1 to 5 . The lowest score (1) showed very low lecturer job performance and the highest score (5) showed very high job performance of lecturers.

All three scales use in this study will be undergoing validity and reliability tests. This is done because the three scales are instruments that are adapted and have been through the process of language translation. In addition, the items used are only items that are in accordance with the purpose and direction of this study.

The Structural Equation Modeling (SEM) will be utilized for the analysis of data.

\section{Result and Discussion}

This study is one of the few efforts to understand whether and how job involvement relates to job performance and to test the mediating role of effort in this relationship. The approach used in this study is a quantitative approach with non-experimental design and uses a correlational pattern that intends to explain the position and relationship of the variables studied between one variable and another. From the purpose context, this study is considered applied research since it is based on theories that have existed before. When viewed from its approach, this study is categorized as survey research, because the data studied is from samples taken from the population.

\section{Conclusion}

The present study for the first time considers effort and its social psychology framework in order to provide a theoretical explanation to behavioral consequences of job involvement. As this study is limited to Eastern Indonesian context and cannot be considered conclusive, certainly further research is necessary to support our propositions. Further research may replicate this study in other Western countries, considering other possible mediators, for example professional identification or perceived organizational support. 


\section{References}

Blau, G. J. (1993) Operationalizing Direction and Level of Effort and Testing Their Relationships to Individual Job Performance. Organizational Behavior and Human Decision Processes, 55, 152-170.

Brown, S. P (1996) A Meta-analysis and Review of Organizational Research on Job Involvement. Psychological Bulletin, 120 (2): 235-255.

Brown, S. P., \& Leigh, T. W (1996) A New Look at Psychological Climate and Its Relationship to Job Involvement, Effort, and Performance. Journal of Applied Psychology, 81 (4): 358-368.

Campbell, J.P., \& Pritchard, R.D. (1976) Motivation Theory in Industrial and Organizational Psychology, in Hand-book of Industrial and Organizational Psychology, Marvin Dunnette, ed. Chicago: Rand-McNally, 63-130.

Chughtai, A. A (2008) Impact of Job Involvement on In-Role Job Performance and Organizational Citizenship Behaviour, Journal of Behavioral and Applied Management, 9 (2): 169-183.

Diefendorff, J. M., Brown, D. J., Kamin, A. M., \& Lord, R. G (2002) Examining the Roles of Job Involvement and Work Centrality in Predicting Organizational Citizenship Behaviors and Job Performance. Journal of Organizational Behavior, 23, 93-108.

Dubinsky, A.J., \& Hartley, S.W. (1986). A path-analytic study of a model of salesperson performance. Academy of Marketing Science, 14(1), 36-46.

Eisenberger, R. (1998). Achievement: The importance of industriousness. Behavioral and Brain Sciences, 21, 412-413.

Fortunato, R.T and Waddell, G. (1981). Personnel Administration in Education; Handbook of Faculty and Staff Personnel Practices. London: Jossey-Bass.

Gardner, D. G., Dunham, R. B., Cummings, L. L., \& Pierce, J. L. (1989) Focus of Attention at Work: Construct Definition and Empirical Validation. Journal of Occupational Psychology, 62, 6177.

Hackman, R. R., \& Lawler, E.E III. (1971) Employee Reactions to Job Characteristics. Journal of Applied Psychology, 55 (3): 259-286.

Hettiararchchi, H.A.H., \& Jayarathna, S.M.D.Y. (2014) The effect of Employee Work Related Attitudes on Employee Job Performance: A Study of Tertiary and Vocational Education Sector in Sri Lanka. Journal of Business and Management, 16 (4): 74-83.

Kahn, W.A. (1990) Psychological Conditions of Personal Engagement and Disengagement at Work. The Academy of Management Journal, 33 (4) :692-724.

Kanungo, R.N., (1982) Measurement of Job and Work Involvement. Journal of Applied Psychology, 67 (3): 341-349.

Lawler, E.E. (1986). High involvement Management: Participative Strategies for Improving Organizational Performance. San Francisco: Jossey-Bass.

Lawler, E.E. and D.T. Hall, 1970. Relationship of job characteristics to job involvement, satisfaction and intrinsic motivation. Journal of Applied Psychology, 54(4): 305-312.

Lloyd, R (2008) Discretionary Effort and the Performance Domain. The Australian and New Zealand Journal of Organisational Psychology, 1, pp 22-34.

Lodahl, T.M. dan Kejner, M. (1965) "The definition and measurement of job involvement", Journal of Applied Psychology, 49 (1): 24-33.

Parsons, T. (1968). The Structure of Social Action. New York: Free Press

Paullay, I.,M., Alliger, G.M., \& Stone-Romero, E (1994) Construct Validation of Two Instruments Designed to Measure Job Involvement and Work Centrality. Journal of Applied Psychology, 79 (2): 224-228.

Pfeffer, J. (1994) Competitive Advantage Through People: Unleashing the Power of the Work Force. Harvard Business School Press: Boston.

Rabinowitz, S., \& Hall, D.T. (1977) Organizational Research on Job Involvement, Psychological Bulletin, 84 (2): 265-288. 
Robbins, S.P. \& Judge, T. A. (2013) Organizational Behavior (Fifteen Edition).Upper Saddle River: New Jersey, Pearson Prentice Hall.

Staw, B.M., Nancy, E.B., \& Clausen, J.A (1986) The Dispositional Approach to Job Attitudes: A Lifetime Longitudinal Test. Administrative Science Quarterly, 31 (1): 56-77.

Steers, R.M., Mowday, R.T., dan Shapiro, D.L (2004) The future of work motivation theory. Academy of Management Review, 29 (3): 379-387.

Yoshimura, A. (1996). A Review and Proposal of Job Involvement (Festschrift for Prof. Yoko Sano). Keio Business Review, 33, 175-184. 